\title{
Observations on the natural history of the lizard Mabuya macrorhyncha Hoge (Scincidae) in Queimada Grande Island, São Paulo, Brazil
}

\author{
Davor Vrcibradic ${ }^{1,2}$ \& Carlos F. D. Rocha ${ }^{1}$ \\ ${ }^{1}$ Departamento de Ecologia, Instituto de Biologia, Universidade do Estado do Rio de Janeiro. Rua São Francisco Xavier 524, \\ Maracanã, 20550-019 Rio de Janeiro, Rio de Janeiro, Brasil. \\ 2 Corresponding author. E-mail: davor@centroin.com.br
}

\begin{abstract}
Data are presented on the on diet, thermal biology, microhabitat use, reproduction and helminth infection parameters of a population of Mabuya macrorhyncha Hoge, 1946 inhabiting the small island of Queimada Grande, on the southern coast of São Paulo State. The lizards were collected on November 1997 (spring) and on July 1998 (winter). Most lizards were perched above ground, mainly on herbaceous vegetation. Mean lizard body temperatures were significantly higher in spring $\left(32.6 \pm 1.9^{\circ} \mathrm{C}\right)$ than in winter $\left(28.5 \pm 2.4^{\circ} \mathrm{C}\right)$, as were air temperatures. Mean litter size of females was 2.7 (range 2-3). The diet was composed of a diverse array of arthropods and some small fruits. Of the 19 lizards examined, 16 (84.2\%) harboured helminths. Three species of helminth (one acanthocephalan and two nematodes) were found infecting the lizards. Compared to other M. macrorhyncha populations previously studied in mainland areas, the Queimada Grande population appears to be less strongly associated to bromeliads, to consume plant matter (fruits) more frequently, and to have a poorer helminth fauna.

KEY WORDS. Diet, endoparasites, insular habitat, skink, thermal biology.
\end{abstract}

RESUMO. Observações sobre a história natural do lagarto Mabuya macrorhyncha Hoge (Scincidae) na Ilha da Queimada Grande,São Paulo, Brasil. Dados são apresentados referentes à dieta, biologia térmica, uso de microhabitats, reprodução e parâmetros de infecção por helmintos de uma população de Mabuya macrorhyncha Hoge, 1946 habitando a pequena ilha da Queimada Grande, na costa sul do Estado de São Paulo. Os lagartos foram coletados em novembro de 1997 (primavera) e em julho de 1998 (inverno). A maioria dos lagartos foi encontrada empoleirada acima do solo, principalmente sobre vegetação herbácea. As temperaturas corpóreas médias dos lagartos foram significativamente mais altas na primavera $\left(32,6 \pm 1,9^{\circ} \mathrm{C}\right)$ do que no inverno $\left(28,5 \pm 2,4^{\circ} \mathrm{C}\right)$, como ocorreu com as temperaturas do ar. $\mathrm{O}$ tamanho médio de ninhada das fêmeas foi de 2.7 (amplitude 2-3). A dieta foi composta por artrópodes variados e por alguns pequenos frutos. Dos 19 lagartos examinados, 16 (84.2\%) estavam infectados por helmintos. Três espécies de helmintos (um acantocéfalo e dois nematódeos) foram encontrados infectando os lagartos. Quando comparada a outras populações de M. macrorhyncha previamente estudadas em áreas continentais, a população da Queimada Grande parece ser menos fortemente associada a bromélias, consumir material vegetal (frutos) mais freqüentemente, e ter uma fauna de helmintos mais pobre.

PALAVRAS CHAVE. Ambiente insular, biologia termal, dieta, endoparasitas, scincideo.

Mabuya macrorhyncha Hoge, 1946 is a skink endemic to the Atlantic rainforest biome of eastern Brazil, where it ranges from the states of Paraíba to São Paulo (Rodrigues 2000), including several small islands off the São Paulo coast (REBOUÇAS-SPIEKER 1974). Several aspects of its ecology have been studied in restinga habitats from coastal areas in the states of Rio de Janeiro and Espírito Santo (Rocha \& VRCibradic 1996, 1999, VRCibradic \& Rocha 1995a, 1996, 2002a, VRCibradic et al. 2002, Hatano et al. 2001). However, little information is available on insular populations of M. macrorhyncha. VANZOLINI \& REBOUÇAS-SPIEKER (1976) studied aspects of the reproduction and life history of both mainland and insular populations along the south coast of São Paulo State. ZANotTi et al. (1997) reported the parturition in February 1996 of a captive female originally collected at Queimada Grande island. Regarding this latter locality, there is also recently published information on infection patterns by ectoparasites (VRCIBradic et al. 2000) and by nematodes (Rocha \& VRCIBRADIC 2003) associated to M. macrorhyncha.

In the present study, data on the on diet, thermal biology, microhabitat use, reproduction and helminth infection parameters of an insular population of M. macrorhyncha are presented, based on specimens collected by the first author during two field trips to Queimada Grande island, on the southern coast of São Paulo State. Some ecological data from these same animals have already been published elsewhere (VRCIBRADIC et al. 2000, Rocha \& VRcibradic 2003). 


\section{MATERIAL AND METHODS}

Queimada Grande island $\left(24^{\circ} 29^{\prime} \mathrm{S} ; 46^{\circ} 41^{\prime} \mathrm{W}\right.$; maximum elevation: $200 \mathrm{~m}$ ) is located ca. $30 \mathrm{~km}$ off the southern coast of São Paulo State. The southern São Paulo coast is an area of high annual rainfall, with an annual mean of more than 2200 $\mathrm{mm}$, though there is a sensible decrease in precipitation (and temperatures) during the autumn-winter months (SILVA 1989). Queimada Grande is a small (ca. $430 \mathrm{~km}^{2}$ ) rocky island mostly covered by rainforests and, to a lesser extent, grasslands (DUARTE et al. 1995). This island is famous for the occurrence of an endemic pitviper, the golden lancehead-Bothrops insularis (Amaral, 1921), which is found there in high densities (CAMPBELL \& LAMAR 2004). The golden lancehead has been reported to prey on M. macrorhyncha (DUARTE et al. 1995), though the frequency with which this occurs is not known. Only two other lizards (excluding amphisbaenians) occur sympatrically with $M$. macrorhyncha on Queimada Grande island: the diurnal gymnophtalmid Colobodactylus taunayi Amaral, 1933 and the exotic nocturnal gekkonid Hemidactylus mabouia (Moreau de Jonnés, 1818) (DuARTE et al. 1995).

The lizards were collected with a pellet rifle by the first author during two field excursions to Queimada Grande, on November 1997 (spring) and on July 1998 (winter). For each lizard, the time of capture and the microhabitat it was using when first sighted were recorded. For lizards perched above ground, the height of the perch was taken with a measuring tape and recorded the type of perch. Each lizard's cloacal temperature, as well as the temperature of the air $1 \mathrm{~cm}$ above the spot where it was originally sighted were taken with a quickreading thermometer (temperatures were ignored if lizards took more than 30s to be captured or if they were too damaged during collection). Differences in mean lizard body temperatures and in mean air temperatures between seasons were tested using one-way Analysys of Variance (ANOVA).

In the laboratory, the lizards were measured in their snout-vent length (SVL) with digital calipers, and then dissected for verification of sex, examination of gonads and excision of the digestive tract. The tails of all lizards were also examined for evidences of regeneration, to estimate tail autotomy rates. Females were checked for the presence of ova or embryos, and their reproductive stage was assessed according to the categories of Rocha \& VRcibradic (1999). Stomachs were opened and their contents were examined under a stereomicroscope. Arthropodan prey were all identified to the taxonomic level of Order. For each food item found we measured its lenght and width with a digital caliper (to the nearest $0.1 \mathrm{~mm}$ ) and calculated its volume using the formula for an ellipsoid: $\mathrm{V}=4$ / 3 p(length/2) (width/2) ${ }^{2}$ (Dunham 1983). Mean prey size was calculated as the average length of all identifiable prey items. Stomachs, intestines and body cavities of all lizards were checked for the presence of helminths. Usage of terms such as "prevalence" and "infection intensity" throughout the text follows Bush et al. (1997).
All lizards collected for the present study are currently deposited at the Museu Nacional, Rio de Janeiro (collection numbers: MNRJ 7286-7304).

\section{RESULTS}

Eight lizards (seven females, one male) were collected in November 1997 and eleven lizards (five females, six males) in July 1998. The 19 individuals averaged $67.1 \pm 6.8 \mathrm{~mm}$ (range 56.5-78.6 mm) in SVL and 17 (89.5\%) of them presented evidences of tail regeneration resulting from previous autotomy.

All lizards were collected between 09:30 h and 15:30 h. Most of the animals (13) were collected at the forest edge, including open areas around the lighthouse, with the remaining animals being collected inside the forest (three) and on the grassland area (three). Mean height above ground for all lizards was $44.0 \pm 44.8$ (range $0-150$ ) $\mathrm{cm}$. Fifteen (78.9\%) individuals were perched above ground. Perches used included herbaceous vegetation, tree trunks or branches, shrubs, rocks and even a rusty metal structure. The frequency of occurrence of lizards in each microhabitat type is shown in figure 1 .

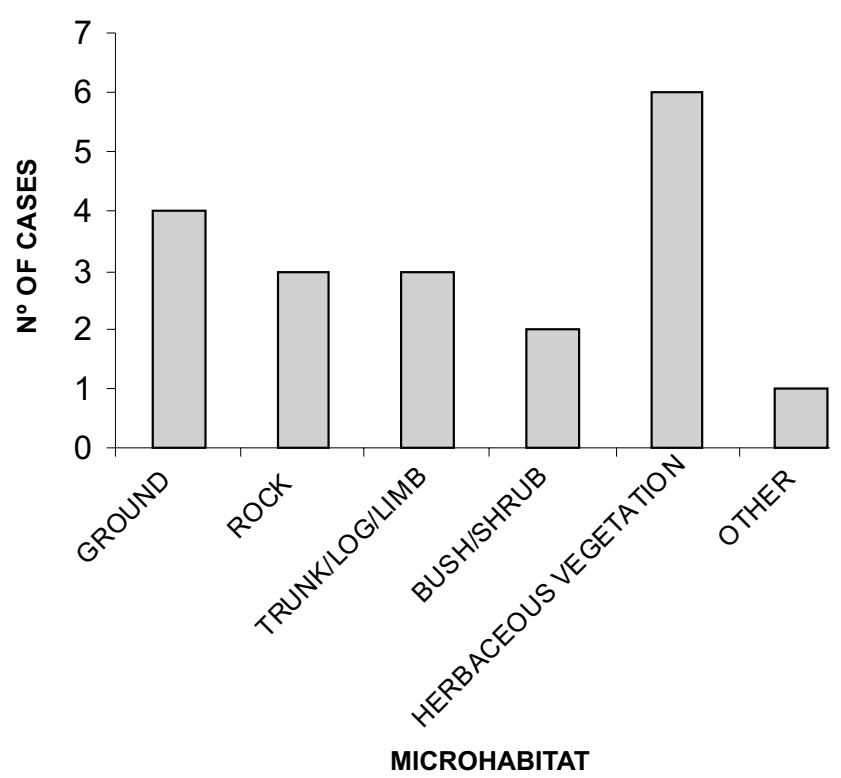

Figure 1. Frequency of utilization (expressed as number of recorded cases) of each microhabitat type by Mabuya macrorhyncha $(\mathrm{N}=$ 19) from Queimada Grande island.

Mean body and air temperatures were significantly higher in spring than in winter (Tab. I). There was no significant correlation between lizard body temperatures and air temperatures in either season ( $\mathrm{p}>0.1$ ), probably due to the small sample sizes.

Mean litter size was $2.7 \pm 0.5$ (range $2-3 ; \mathrm{N}=9$ ). Of the seven females collected in November, three were in stage 6 of 
Table I. Mean body and air temperatures (with sample size in parentheses and ranges in brackets) of Mabuya macrorhyncha in Queimada Grande island, with the results of ANOVAs used to test for differences between months.

\begin{tabular}{lcc}
\hline \multicolumn{1}{c}{ Month } & Body temperature & Air temperature \\
\hline November 1997 & $32.6 \pm 1.9^{\circ} \mathrm{C}(7)$ & $29.1 \pm 2.1^{\circ} \mathrm{C}(7)$ \\
& {$\left[29.8-34.6^{\circ} \mathrm{C}\right]$} & {$\left[25.0-31.6^{\circ} \mathrm{C}\right]$} \\
June 1998 & $28.5 \pm 2.4^{\circ} \mathrm{C}(11)$ & $25.1 \pm 2.1^{\circ} \mathrm{C}(11)$ \\
& {$\left[25.6-32.6^{\circ} \mathrm{C}\right]$} & {$\left[21.6-29.2^{\circ} \mathrm{C}\right]$} \\
\hline ANOVA & $\mathrm{F} 1,16=14.5 ; \mathrm{p}<0.005$ & $\mathrm{~F} 1,16=15.0 ; \mathrm{p}=0.001$ \\
\hline
\end{tabular}

Rocha \& VRCibradic (1999; i.e. near-term or term embryos), one was in stage 5 (embryos occupying most of embryo sac, though not yet totally developed), one was in stage 2 (yolked follicles but no oviductal ova), and two were in stage 1 (no yolking follicles or oviductal ova). The latter were both smaller than 60 $\mathrm{mm}$ and, therefore, probably immature (see VANzolinI \& Rebouças-Spieker 1976). All five females collected in July had oviductal ova measuring $5-8 \mathrm{~mm}$ in diameter, containing poorly developed embryos (stage 4 of Rocha \& VRCiBradic 1999).

All individuals from spring and nine (90\%) from winter had food in their stomachs (one individual from July was not considered for dietary analysis, as its stomach had been damaged during collection). Mean number of prey items per stomach for the eight animals collected in November 1997 was 9.1 \pm 6.0 (range 2-22) whereas the nine individuals from July 1998 with prey in stomachs contained a single prey item each (excluding plant material). Mean total food volume per stomach was $301.4 \pm 172.9$ (range 26.8-514.0) $\mathrm{mm}^{3}$ in November 1997 and $142.5 \pm 139.1$ (range $5.4-401.7$ ) $\mathrm{mm}^{3}$ in July 1998. Diet was composed of a diverse array of arthropods and some plant material (small fruits) (Tab. II).

Of the 19 lizards examined, 16 (84.2\%) harboured helminths. Three helminth species were found infecting $M$. macrorhyncha on Queimada Grande: one unidentified acanthocephalan (Centrorhynchidae) and two nematodes - Parapharyngodon sceleratus (Travassos 1923) and an unidentified acuariid. The acanthocephalan and the acuariids were found only as immature forms (cystacanths and larvae, respectively). Since there was no significant difference in the prevalence of acanthocephalans (Z-test; $p>0.1$ ) or acuariids (Z-test; $p>0.1$ ) between seasons (no testing was done for P. sceleratus, as it was found in only two individuals, both collected in November 1997), we treated our samples from both seasons as a single one (i.e. we pooled the data). Epidemiological data for each helminth species is given in table III. There was no relationship between infection intensity and host SVL for neither the acanthocephalan $(\mathrm{r}=0.37 ; \mathrm{p}=0.15)$ nor the acuariid $(\mathrm{r}=0.17 ; \mathrm{p}=0.57)$. The mean helminth richness per host was $1.63 \pm 0.89$ considering all lizards and $1.94 \pm 0.57$ (range 1-3) considering only infected lizards. Among the later, helminth richness was not significantly related to host SVL $(\mathrm{r}=0.39 ; \mathrm{p}=0.14 ; \mathrm{N}=16)$.

\section{DISCUSSION}

Rebouças-SPIEKer (1974) mentioned that M. macrorhyncha is bromelicolous on the coastal mainland of São Paulo State and on the offshore islands of Búzios and Alcatrazes (she does not mention having data for other islands), and observations on other populations from restinga habitats in the states of Rio de Janeiro, Espírito Santo (Rocha \& Vrcibradic 1996, Vrcibradic \& Rocha 1996, 2002a), Bahia (unpubl. data), Paraíba and Rio Grande do Norte (FreIre 1996) also indicate strongly bromelicolous habits. At Queimada Grande island, however, no individuals were collected (or seen) in bromeliads in the present study. Bromeliads were not conspicuously abundant in the habitats where our collections were done (or, at least, not as abundant as they are in restingas). Saxicolous bromeliads occur in high denstities on the rocky slopes that marginate the island, but those habitats were not sampled due to inacessibility. Although bromeliads were commonly found inside the forest, they were usually in the shade and did not form large aggregations as they do in restingas, so that they may not represent ideal sites for basking and shelter for the skinks in that habitat. Our observations suggest that M. macrorhyncha may not be strongly bromelicolous at Queimada Grande, unlike other areas where it occurs, but its scansorial habits are still evident and it may use most or all types of perches available throughout the island.

Body temperatures of M. macrorhyncha collected during the warmer season (spring) in the study area were similar to that reported for other conspecific populations also studied during spring-summer months (Hatano et al. 2001, VRCIBRAdic \& Rocha 2002a). The significantly lower body and air temperatures recorded in July suggest that the thermal environment for the $M$. macrorhyncha population of Queimada Grande may vary seasonally. In the southern coast of São Paulo state, there is an amplitude of about $7^{\circ} \mathrm{C}$ in air temperature between the warmest and coolest months of the year (SILVA 1989), and this variation is likely to influence the thermal biology of the skinks which, like all lizards, depend on external heat sources for their metabolism.

Vanzolini \& Rebouças-Spieker (1976) found that $M$. macrorhyncha from Queimada Grande had the smallest broods of all seven populations (both continental and insular) of that species surveyed in their study. As much as $69 \%$ of their sample of 51 pregnant females had broods of two and $10 \%$ had broods of one (brood size ranged from 1 to 4 , averaging 2.2). In our data from the same locality, only three (33\%) of the nine examined females had broods of two, with the remaining six $(67 \%)$ having broods of three. In spite of the discrepancy in sample sizes between our study and that of VANZOLINI \& REBOUÇASSPIEKER (1976), our data are suggestive that the incidence of larger broods may have increased since the time of the former study. It is not possible to know whether this was a gradual process of if mean brood size may actually vary among years in this population. The latter possibility does not seem implausible, as fecundity presumably depends on the availability of energy 
Table II. Representativeness [by volume (in $\mathrm{mm}^{3}$ ), number, and frequency of occurrence] of each prey category in the diet of Mabuya macrorhyncha from Queimada Grande island collected in two different months. Plant material (fruit remains) were not quantified, as it was not always possible to determine the number of items ingested. Arthropod remains that were too fragmented to identify were grouped under the category "Miscellany".

\begin{tabular}{|c|c|c|c|c|c|c|}
\hline \multirow{2}{*}{ Items } & \multicolumn{3}{|c|}{ November $1997(n=8)$} & \multicolumn{3}{|c|}{ July $1998(n=10)$} \\
\hline & V(\%) & $\mathrm{N}(\%)$ & $\mathrm{F}$ & V(\%) & $\mathrm{N}(\%)$ & $\mathrm{F}$ \\
\hline \multicolumn{7}{|l|}{ Insecta } \\
\hline Blattaria & $201.1 \quad(8.4)$ & $3(4.2)$ & 2 & & & \\
\hline Coleoptera & $713.8(29.6)$ & $3(4.2)$ & 2 & $34.5(2.7)$ & $2(22.2)$ & 2 \\
\hline Diptera & $107.3(4.5)$ & $6 \quad(8.5)$ & 1 & $24.5(1.9)$ & $1(11.1)$ & 1 \\
\hline Embioptera & $1.3(0.05)$ & $1(1.4)$ & 1 & & & \\
\hline Hemiptera & $13.1(0.5)$ & $13(18.3)$ & 1 & & & \\
\hline Homoptera & $3.3(0.1)$ & $2(2.8)$ & 1 & & & \\
\hline \multicolumn{7}{|l|}{ Hymenoptera } \\
\hline Formicidae & $305.8(12.7)$ & $8(11.3)$ & 1 & & & \\
\hline Others & $15.6(0.6)$ & $3(4.2)$ & 2 & & & \\
\hline Isoptera & $1.0(0.04)$ & $1(1.4)$ & 1 & & & \\
\hline Lepidoptera & $6.2(0.3)$ & $1(1.4)$ & 1 & $410.6(32.0)$ & $2(22.2)$ & 2 \\
\hline Orthoptera & $247.6(10.3)$ & $2(2.8)$ & 2 & $6.4 \quad(0.5)$ & $1(11.1)$ & 1 \\
\hline Phasmida & $146.5(6.1)$ & $1(1.4)$ & 1 & & & \\
\hline Larvae & $229.8 \quad(9.5)$ & $6 \quad(8.5)$ & 3 & $193.0(15.0)$ & $2(22.2)$ & 2 \\
\hline \multicolumn{7}{|l|}{ Arachnida } \\
\hline Aranae & 152.4 (6.3) & $9(12.7)$ & 4 & $14.7 \quad(1.2)$ & $1(11.1)$ & 1 \\
\hline \multicolumn{7}{|l|}{ Myriapoda } \\
\hline Chilopoda & $160.2(6.6)$ & 1 (1.4) & 1 & & & \\
\hline \multicolumn{7}{|l|}{ Crustacea } \\
\hline Isopoda & $52.5 \quad(2.2)$ & $11(15.5)$ & 3 & & & \\
\hline \multicolumn{7}{|l|}{ Plant matter } \\
\hline Fruits & $8.3 \quad(0.3)$ & - & 1 & $497.5(38.8)$ & - & 2 \\
\hline Miscellany & $45.5 \quad(1.9)$ & - & - & $101.4(7.9)$ & - & - \\
\hline Total & 2411.3 & 71 & & 1282.6 & 9 & \\
\hline
\end{tabular}

Table III. Prevalences (in numbers and percentages), infection intensities (mean \pm one SD, with range in parentheses) and sites of infection ( $\mathrm{S}=$ stomach, $\mathrm{SW}=$ stomach wall, $\mathrm{I}=$ intestines, $\mathrm{L}=$ liver, $\mathrm{P}=$ peritoneum, $\mathrm{C}=$ coelom $)$ of helminth species associated to Mabuya macrorhyncha $(\mathrm{N}=19)$ from Queimada Grande island, Coastal São Paulo State, Brazil.

\begin{tabular}{lccc}
\hline \multicolumn{1}{c}{ Helminth species } & Prevalence (\%) & Infection intensity & Infection site \\
\hline Acanthocephala & & & \\
Centrorhynchidae & $13(68.4)$ & $4.5 \pm 3.9(1-12)$ & SW, P, L \\
Nematoda & & & \\
Acuariidae & $16(84.2)$ & $9.8 \pm 9.5(1-29)$ & SW, S, I, C \\
Parapharyngodon sceleratus & $2(10.5)$ & 2.0 & I \\
\hline
\end{tabular}

sources (such as food) for females, and such resources are likely subject to inter-annual variation in isolated and presumably unstable habitats such as small islands.

Mabuya macrorhyncha from Queimada Grande fed on a diverse array of arthropods, as in another conspecific population from the mainland (VRCIBRADIC \& Rocha 1996). It is inter- esting to note that in the latter study, as in the present one, colonial insects (i.e. ants and termites) were not very important items in the diet, which suggests that M. macrorhyncha may not feed on colonial insects to a significant extent, as do some other Brazilian congeners (M. agilis (Raddi, 1823) (VRcibradic \& Rocha 1995b, 1996); M. frenata (Cope, 1862) 
(VRCIBRADIC et al. 1998). Although our sample sizes are small for making statements, it is worth noting that the animals collected during the wetter, warmer period (spring) had a greater rate of prey ingestion than those collected during the drier, cooler period (winter). Seasonal variations in prey abundance, which are common in the so-called "seasonal tropics", may result in differences in the rates of prey ingestion and/or the diet composition of lizards among seasons (vaN SLUYs 1995, Rocha 1996, Vrcibradic et al. 1998). Three (ca. 17\%) of the 18 lizards whose stomachs were analysed contained fruit remains. Additionally, a single juvenile specimen (41.5 mm SVL) collected by researchers of the Instituto Butantan during a field trip to the island on February 2000 had remains of fruit peel, among various arthropodan prey, in its stomach (unpubl. data). This suggests that the consumption of plant material (fruits) may not be uncommon among M. macrorhyncha from Queimada Grande. In a conspecific mainland population studied by VRCibradic \& Rocha (1995a, 1996) in a restinga of Rio de Janeiro State, consumption of plant material (fruits and seeds) was relatively infrequent (ca. 3\% frequency of occurrence). Plant consumption is usually higher in insular lizard populations than in mainland ones (COOPER \& ViTT 2002) and our data, though based on a small sample, seems to concur with this trend. Nevertheless, more data on the diets of insular and continental $M$. macrorhyncha populations are needed to verify this.

Only three species of helminths were found associated to M. macrorhyncha in the present study, indicating a poor helminth community for this insular population, compared to other conspecific populations from restinga habitats in the mainland (6-8 helminth species per host population; see table I of Rocha et al. 2003). This agrees with the idea that lizard populations from small islands tend to have more depauperate helminth communities than those from the mainland or large islands (Dobson et al. 1992, Roca et al. 1999). Nevertheless, overall prevalence of infection was high in M. macrorhyncha from Queimada Grande. Lizard populations inhabiting islands often present higher helminth prevalences than conspecific or congeneric populations from the mainland, though this may not always occur (Roca 1995, Rocha \& VRCIBRADIC 2003). The most prevalent helminth parasites of the studied population of M. macrorhyncha were immature forms (acuariid larvae and centrorhynchid cystacanths) which apparently use the lizards as paratenic or intermediate hosts. Since the final hosts for both these parasites are likely to be predatory birds (Dobson et al. 1992, Roca et al. 1999, SHARPILO et al. 2001), this suggests that predation on M. macrorhyncha by birds may be frequent at Queimada Grande island. Owls and hawks have been reported as predators of the snake Bothrops insularis on Queimada Grande (DUARTE et al. 1995), and these birds are likely to prey on the Mabuya as well. Predation pressure on these lizards in the island is also suggested by the high rates of tail autotomy observed (i.e. regenerated tails in 90\% of the lizards examined). Nevertheless, high rates of tail loss are apparently characteris- tic of New World Mabuya and may not be a result of predation pressure alone (van SLuYs et al. 2002, VRCIBRAdic \& Rocha 2002b).

\section{ACKNOWLEDGMENTS}

This study is a portion of the results of the "Programa de Ecologia, Conservação e Manejo de Ecossistemas do Sudeste Brasileiro" and of the Southeastern Brazilian Vertebrate Ecology Project (Vertebrate Ecology Laboratory), both of the Departamento de Ecologia, Universidade do Estado do Rio de Janeiro. We thank O.A.V. Marques, M.R. Duarte, F.L. Franco, D.S. Fernandes, A. Eterovic, C. Falcetti, C. Nogueira and P. H. Valdujo of the Bothrops insularis project for making it possible for the senior author to participate on their field excursions to Queimada Grande island. We also thank S. A. A. Morato and an anonymous referee for reviewing the manuscript. During the development of this study C.F.D.Rocha (processes \# 307653/03-0 and 477981/03-8) and D. Vrcibradic (process \# 143607/98-7) benefitted from grants from the Conselho Nacional do Desenvolvimento Científico e Tecnológico - CNPq, and also fom a research grant from FAPERJ (Process E-26/170.385/97-APQ1).

\section{REFERENCES}

Bush, A.O.; K.D. Lafferty; J.M. Lotz \& A.W. Shostak. 1997. Parasitology meets ecology in its own terms: Margolis et al. revisited. Journal of Parasitology, Washington, 83 (4): 575-583.

Campbell, J.A. \& W.W. Lamar. 2004. The venomous reptiles of the Western Hemisphere. Ithaca, Cornell University Press, 870p.

Cooper, W.E. \& L.J. VitT. 2002. Distribution, extent, and evolution of plant consumption by lizards. Journal of Zoology, London, 257 (4): 487-517.

Dobson, A.P.; S.V. Pacala; J.D. Roughgarden; E.R. Carper \& E.A. HARRIs. 1992. The parasites of Anolis lizards in the northern Lesser Antilles I. Patterns of distribution and abundance. Oecologia, Berlin, 91 (1): 110-117.

DunHAM, A.E. 1983. Realized niche overlap, resource abundance and intensity of interspecific competition. p. 261-280. In: R.B. Huey; E.R. Pianka \& T.W. Schoener (Eds.). Lizard ecology: studies of a model organism. Cambridge, Harvard University Press, 501p.

Duarte, M.R.; G. Puorto \& F.L. Franco. 1995. A biological survey of the pitviper Bothrops insularis Amaral (Serpentes, Viperidae): an endemic and threatened offshore island snake of southeastern Brazil. Studies on Neotropical Fauna and Environment, Tübingen, 30 (1): 1-13.

Freire, E.M.X. 1996. Estudo ecológico e zoogeográfico sobre a fauna de lagartos (Sauria) das dunas de Natal, Rio Grande do Norte e da restinga de Ponta de Campina, Cabedelo, Paraíba, Brasil. Revista Brasileira de Zoologia, Curitiba, 13 (4): 903-921.

Hatano, F.H.; D. Vrcibradic; C.A.B. Galdino; M. Cunha-Barros; C.F.D. Rocha \& M. van Sluys. 2001. Thermal ecology and

Revista Brasileira de Zoologia 22 (4): 1185-1190, dezembro 2005 
activity patterns of the lizard community of the restinga of Jurubatiba, Macaé, RJ. Revista Brasileira de Biologia, São Carlos, 61 (2): 287-294.

RebouÇAS-SPIEKER, R. 1974. Distribution and differentiation of animals along the coast and in continental islands of the state of São Paulo, Brazil. 2. Lizards of the genus Mabuya (Sauria, Scincidae). Papéis Avulsos de Zoologia, São Paulo, 28 (12): 197-240.

RocA, V. 1995. An approach to the knowledge of the helminth infracommunities of Mediterranean insular lizards (Podarcis spp.), p. 285-292. In: G.A. Llorente; A. Montori; X. SAntos \& M.A. Carretero (Eds). Scientia Herpetologica. Barcelona, Asociación Herpetologica Española, 380p.

Roca, V.; J.E. Martin \& E. CARbonell. 1999. Helminths parasitizing endemic geckoes from Canary Islands. Miscellania Zoologica, Barcelona, 22 (1): 101-108.

RochA, C.F.D. 1996. Seasonal shift in lizard diet: the seasonality in food resources affecting the diet of Liolaemus lutzae (Tropiduridae) in southeastern Brazil. Ciência e Cultura, São Paulo, 48 (4): 264-269.

Rocha, C.F.D. \& D. VRcibradic. 1996. Thermal biology of two sympatric skinks (Mabuya macrorhyncha and Mabuya agilis) in a Brazilian restinga habitat. Australian Journal of Ecology, Carlton, 21: 110-113.

Rocha, C.F.D. \& D. VRCibradic. 1999. Reproductive traits of two sympatric viviparous skinks (Mabuya macrorhyncha and Mabuya agilis) in a Brazilian restinga habitat. Herpetological Journal, Canterbury, 9 (2): 43-53.

Rocha, C.F.D. \& D. VRCibradic. 2003. Nematode assemblage of some insular and continental lizard host of the genus Mabuya Fitzinger (Reptilia, Scincidae) along the eastern Brazilian coast. Revista Brasileira de Zoologia, Curitiba, 20 (4): 755-759.

Rocha, C.F.D.; D. VRcibradic,; J.J. Vicente; M.Cunha-Barros. 2003. Helminths infecting Mabuya dorsivittata (Lacertilia, scincidae) from a high-altitude habitat in Itatiaia National Park, Rio de Janeiro State, southeastern Brazil. Brazilian Journal of Biology, São Carlos, 63 (1): 129-132.

Rodrigues, M. T. 2000. A new species of Mabuya (Squamata: Scincidae) from the semiarid caatingas of northeastern Brazil. Papéis Avulsos de Zoologia, São Paulo, 41 (2): 313-328.

Sharpilo, V.P.; V. Biserkov; A.Kostadinova; J.M. Behnke \& Y.I. Kuzmin. 2001. Helminths of the sand lizard, Lacerta agilis (Reptilia, Lacertidae), in the Palaearctic: faunal diversity and spatial patterns of variation in the composition and structure of component communities. Parasitology, Cambridge, 123 (4): 389-400.

SiLVA, J.F. 1989. Dados climatológicos da Cananéia e Ubatuba (Estado de São Paulo). Boletim Climatológico do Instituto Oceanográfico, São Paulo. 6: 1-21.
Vanzolini, P.E. \& R. Rebouças-Spieker. 1976. Distribution and differentiation of animals along the coast and in continental islands of the state of São Paulo, Brazil. 3. Reproductive differences between Mabuya caissara and Mabuya macrorhyncha (Sauria, Scincidae). Papéis Avulsos de Zoologia, São Paulo, 29 (15): 95-109.

VAN SLuYs, M. 1995. Seasonal variation in prey choice by the lizard Tropidurus itambere (Tropiduridae) in southeastern Brazil. Ciência e Cultura, São Paulo, 47 (1/2): 61-65.

van Sluys, M.; D. Vrcibradic \& C.F.D. Rocha.2002. Tail loss in the syntopic lizards Tropidurus itambere (Tropiduridae) and Mabuya frenata (Scincidae) in southeastern Brazil. Studies on Neotropical Fauna and Environment, Tübingen, 37 (3): 227-231.

VRCibRADIC, D. \& C.F.D. Rocha. 1995a. Variação sazonal na dieta de Mabuya macrorhyncha (Sauria, Scincidae) na restinga de Barra de Maricá, RJ. Oecologia Brasiliensis, Rio de Janeiro, 1: 143-153.

VRCibradic, D. \& C.F.D. Rocha. 1995b. Ecological observations on the scincid lizard Mabuya agilis in a Brazilian restinga habitat. Herpetological Review, Cincinnati, 26 (3): 129-131.

VRCibradic, D. \& C.F.D. Rocha. 1996. Ecological differences in tropical sympatric skinks (Mabuya macrorhyncha and Mabuya agilis) in southeastern Brazil. Journal of Herpetology, Lawrence, 30 (1): 60-67.

VRCIBRADIC, D. \& C.F.D. Rocha. 2002a. Use of cacti as heat sources by thermoregulating Mabuya agilis (Raddi) and Mabuya macrorhyncha Hoge (Lacertilia, Scincidae) in southeastern Brazil. Revista Brasileira de Zoologia, Curitiba, 19 (1): 77 83.

VRCibradic, D. \& C.F.D. Rocha. 2002b. Ecology of Mabuya agilis (Raddi) (Lacertilia, Scincidae) at the restinga of Grumari, Rio de Janeiro, southeastern Brazil. Revista Brasileira de Zoologia, Curitiba, 19 (Supl. 2): 19-29.

Vrcibradic, D.; C.F.D. Rocha; G.M. Teles \& M. Van Sluys. 1998. Dieta conservativa em um ambiente sazonal: o caso de Mabuya frenata (Sauria, Scincidae) em Valinhos, SP. In: Anais do VIII Seminário Regional de Ecologia, São Carlos, vol. 2, p. 857-867.

VRcibradic, D.; M.Cunha-Barros \& C.F.D. Rocha. 2000. Natural history notes. Mabuya macrorhyncha. Ectoparasites. Herpetological Review, Cincinnati, 31 (3): 174-175.

Vrcibradic, D.; C.F.D. Rocha; C.R. Bursey \& J.J. Vicente. 2002. Helminth communities of two sympatric skinks (Mabuya agilis and Mabuya macrorhyncha) from two "restinga" habitats in southeastern Brazil. Journal of Helmithology, Wallingford, 76 (4): 355-361.

ZANOTTI, A.P.; S.S. SANT'ANNA \& J.L.D. LATUF. 1997. Natural history notes. Mabuya macrorhyncha. Reproduction. Herpetological Review, Cincinnati, 28 (3): 152.

Received in 11.IV.2005; accepted in 05.XII.2005.

Revista Brasileira de Zoologia 22 (4): 1185-1190, dezembro 2005 